Hemispheric American Studies 



\section{Hemispheric American Studies}

Edited by

CAROLINE F. LEVANDER

and ROBERT S. LEVINE

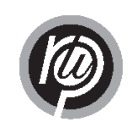

RUTGERS UNIVERSITY PRESS

NEW BRUNSWICK, NEW JERSEY, AND LONDON 


\section{LIBRARY OF CONGRESS CATALOGING-IN-PUBLICATION DATA}

Hemispheric American studies / edited by Caroline F. Levander and Robert S. Levine.

p. $\mathrm{cm}$.

Includes bibliographical references and index.

ISBN 978-0-8I35-4222-5 (hardcover : alk. paper) — ISBN 978-o-8I35-4223-2 (pbk. : alk. paper)

I. America-Civilization. 2. America-Study and teaching (Higher) 3. Western Hemisphere-Study and teaching (Higher) 4. United States-Study and teaching (Higher) 5. America-Race relations. 6. Migrations of nations. 7. AmericaIntellectual life. 8. American literature-History and criticism. 9. Latin American literature-History and criticism. Io. Ethnic groups in literature.

I. Levander, Caroline Field II. Levine, Robert S. (Robert Steven)

E2O.H46 2008

970-dc22

20070I27I5

A British Cataloging-in-Publication record for this book is available from the British Library.

This collection copyright ( 2008 by Rutgers, The State University

Individual chapters copyright (C) 2008 in the names of their authors unless otherwise noted below.

Earlier versions of chapters 4, 6, 9, I3, and I4 were previously published in American Literary History, Vol. I8 (3).

Used by permission of Oxford University Press.

All rights reserved

No part of this book may be reproduced or utilized in any form or by any means, electronic or mechanical, or by any information storage and retrieval system, without written permission from the publisher. Please contact Rutgers University Press, Ioo Joyce Kilmer Avenue, Piscataway, NJ 08854-8099. The only exception to this prohibition is "fair use" as defined by U.S. copyright law.

Visit our Web site: http://rutgerspress.rutgers.edu

Manufactured in the United States of America 